\title{
THE IMPORTANCE OF A REALISTICALLY DETERMINED AMOUNT OF TAX ON PROPERTY RIGHTS RELATING TO THE OWNERSHIP OF AGRICULTURAL LAND IN THE REPUBLIC OF SERBIA ADOPTED BY TAX AUTHORITIES OF LOCAL SELF- GOVERNMENT UNITS
}

Slobodan Popovićl, Jelena Vitomir ${ }^{2}$, Sonja Tomaš-Miskin ${ }^{3}$, Tatjana Davidov ${ }^{4}$, Sanda Nastič ${ }^{5}$, Vera Popović, Dragana Popović ${ }^{7}$, Goran Vitomir ${ }^{8}$

*Corresponding author E-mail: slobodan.popovic49@gmail.com

A R T I C LE IN F O

Original Article

Received: 10 September 2021

Accepted: 01 December 2021

doi:10.5937/ekoPolj2104029P

UDC 336.226.212.1(497.11)

Keywords:

fair value, agricultural machinery, tractors, financial report

JEL: M41, G32, H39
A B S T R A C T

It has been argued for a long time in academic papers which corporate governance factors have a significant impact on gains of a great number of businessmen. However, such studies rarely examine the impact taxation issues on agriculture. This paper differs from other published papers because its focus is tax on agricultural land in an economy in transition. The primary aim of the authors was to find rules in taxpayers' conduct after being served tax decisions issued by local tax authorities with the assessed tax. The following aim was to find out how tax authorities respond to receiving complaints on the assessed tax lodged by the affected tax payers. The conclusions are as follows: first, there is a difference in tax amounts assessed by local tax authorities relating to property rights of taxpayers resulting from their ownership of agricultural land: second, there is a significant difference in tax amounts assessed following the complaints lodged by taxpayers in all four categories of tax rates set by tax authorities for the four respective zones.

(C) 2021 EA. All rights reserved.

1 Slobodan Popovic, PhD, Faculty of Economics and Engineering Management, Cvecarska 2, Novi Sad, Serbia, Phone: +381640483 563, E-mail: slobodan.popovic49@gmail.com, ORCID ID (https://qa.orcid.org/0000-0002-7884-2051)

2 Jelena Vitomir, PhD, Megatrend University, Maršala Tolbuhina 8, 11000 Beograd, Serbia, E-mail: jelena.vitomir1@gmail.com, ORCID ID (https://orcid.org/0000-0001-6995-3297)

3 Sonja Tomaš-Miskin PhD, School of Economics Banja Luka, Kralja Alfonsa XIII, Banja Luka 78000, Bosnia \& Herzegovina, ORCID ID (https://orcid.org/0000-0003-3780-9228)

4 Tatjana Davidov, Infostan Tehnologije d.o.o. Beograd, 1, Danijelova 33, 11010 Beograd, Serbia, E-mail: tanja.davidov1@gmail.com, ORCID ID (https://qa.orcid.org/0000-0002-8926-8913)

5 Sanda Nastic, PhD, JKP Vodovod i kanalizacija, Novi Sad, Masarikova 17, 21000 Novi Sad, Serbia, Phone: +381 0214888 3333, E-mail: sanda.nastic@vikns.rs, ORCID ID (https:// qa.orcid.org/0000-0002-9500-6629)

6 Vera Popovic, PhD, Institute of Field and Vegetable Crops, Maksim Gorkog, 30, Novi Sad, Serbia, E-mail: vera.popovic@ifvens.ns.ac.rs, ORCID ID (https://qa.orcid.org/0000-0001-6032-6457)

7 Dragana Popović, Faculty of Economics, Subotica, Dr Sime Miloševića 16, Novi Sad 210000, Serbia, E-mail: draaaganap@gmail.com, ORCID ID (https://orcid.org/0000-0002-3023-5877)

8 Goran Vitomir, Nova Banka A.D Banja Luka, 78000 Banja Luka, Bosnia and Hercegovina, E-mail: g.vitomir85@gmail.com, ORCID ID (https://orcid.org/0000-0003-2672-3250)

http://ea.bg.ac.rs 


\section{Introduction}

Tax authorities of the state (Anwar \& Sun, 2015; Boukalova, et all, 2016; Murphy, 2019) are taxing in accordance with the adopted tax policy (Cantino, 2009; Soltani, 2009; Cai \& Wong, 2010; Nowak, et all., 2016; Ugrenović, et all., 2021) based on ownership over agricultural land. Transitional countries (Santos Curto \& Dias, 2014; Rymanov, 2017; Rodriguez, et all., 2019; Vitomir, et all., 2021), like the Republic of Serbia, adapted continuous agricultural policy to internal socio-economic conditions (Popović, 2014) on the one hand, and on other conditions that prevail in the EU (Williams, 2010; Popović, et all., 2014a; Scalera, 2016; Wynen \& Verhoest, 2016; Novaković, et all., 2018; Wang, 2019)

In addition, countries that want to join the EU are continuously aligning their land management policy (Popović, et all, 2015; Popović, et all., 2018; Radović et all, 2021; Popović, et all., 2021) with agrarian policy in the EU (Barlev \& Hhaddad, 2003; Barker \& McGeachin, 2013; Aczel, 2015; Bozzolan, et all., 2016; Chen, et al., 2017; Alibegović, et all., 2018). Issues related to the management of agricultural enterprises are related to the resolution of internal management decisions (Baráth \& Fertő, 2017; Baker, et all., 2018) but also for the issues of resolving fair valuation both in enterprises and in the economy of the country (Brown \& Szimayer, 2008; Brousseau, et all., 2014; Bratten, et all., 2016).

This paper aims to analyze the impact of the value of the tax on property rights over agricultural land in the Republic of Serbia. The authors point out that agricultural land is constantly under pressure to spread the demand and desire of the population to turn part of the agricultural land into a space for other production-business purposes.

For this reason, the authors have done the research in order to draw the attention of the expert public to the behavior of the transitional country in the conduct of tax policy regarding the existence of ownership over the land in accordance with the distance from the center of the Municipality and the City.

A transitional country on the path to the EU should harmonize tax policy with the generally accepted policy of countries it seeks to join, with the emphasis on the specific features.

\section{Material and methods}

This paper deals with the 2014-2019 period and the research was conducted in the Republic of Serbia. It examines the impact of the amount of tax on agricultural property assessed by local tax administrations. Taxation is a very sensitive issue which might have an impact on a great number of individuals.

The research this paper is about is based on a broader framework of tax rates and it relates to property rights resulting from the ownership of agricultural land. Tax amount management depends on the local self government or city policy as local tax units assess tax to a great number of taxpayers. 
In the period under consideration, 2014-2019, taxpayers were subject to tax on agricultural land if its size exceeded 1/10 ha. In addition to that, agricultural land possessed by a taxpayer needed not be comprised in one plot. The amount of tax was assessed by tax authorities of local self governments or cities on the basis of data stipulated in agricultural land sales agreements concluded in the previous year.

When assessing the tax amount, tax authorities take into account the average value of agricultural land sold, as provided for by the law, and its distance from the centre of the respective place or city. It is provided for by the law that a maximum tax rate set shall be $0.4 \%$ of the market value of agricultural land.

\section{Methods and current research theoretical assumptions and basis of statistical analysis used}

The authors took into account the already published papers (Vukadinović, 1990) and used a relevant sample (size marked with p) of municipalities or cities in the Republic of Serbia (marked with $\mathrm{N}$ ), or pairs of causal data (value of sales tax on agricultural land is marked with $\mathrm{X}$ ) as well as (the value of sales tax on agricultural land determined after the appeal of taxpayers, which is marked with Y).

It was essentially a linear equation:

$$
\gamma=\alpha+\beta \chi
$$

Based on that, it was necessary to determine: $\alpha, \beta$.

This could be described by the linear dependence of what was said. The distribution itself belonged to the group of so-called normal distributions, i.e. $N(0, \sigma 2)$, where $E$ $(\mathrm{x})=0$ (mathematical expectation) where the tax rate from tax solutions is classified by zones away from the center of the municipality or cities.

The authors performed the observation for the interval 1-4 in the observed 6 cities, which are essentially a representative sample that was processed in the study, where the tax rate was $0.3 ; 0.2 ; 0.25$; and 0.4 . Thus, for each pair of causal data, it was valid ( $\mathrm{i}=$ number of municipalities or cities).

$$
\gamma_{j}=\alpha+\beta \chi_{i}
$$

At the same time, the coefficients $\alpha$ and $\beta$ are minimized by using the following expression.

$$
\sum_{i=1}^{n}\left(Y_{i}-Y_{j}\right)^{2}=\sum_{i=1}^{n}\left(Y_{i}-(\alpha+\beta \chi i)\right)^{2}
$$

Based on that, a system of equations was obtained.

$$
\sum_{i=1}^{n} Y_{j}=n \alpha+\beta \sum_{i=1}^{n} \chi j
$$




$$
\sum_{i=1}^{n} \chi j Y_{j}=\alpha \sum_{i=1}^{n} \chi i+\beta \sum_{i=1}^{n} \chi^{2}
$$

The mentioned system of equations has a unique solution in $\alpha$ and $\beta$.

$$
\begin{gathered}
\alpha=\frac{\sum_{i=1}^{n} Y i}{n}-b \frac{\sum_{i=1}^{n} \chi i}{n} \\
\beta=\frac{n \sum_{i=1}^{n} \chi i y i-\left(\sum_{i=1}^{n} \chi i\right)\left(\sum_{i=1}^{n} Y i\right)}{n \sum_{i=1}^{n} \chi i^{2}-\left(\sum_{i=1}^{n} \chi i\right)^{2}}
\end{gathered}
$$

Therefore, $\mathrm{E}(\alpha)=\alpha$; and $\mathrm{E}(\beta)=\beta$.

After that, the authors took into account the relative measure of representativeness, because it can be used to observe which part of the variability of the feature Y can be explained by changing the feature $\mathrm{X}$.

Essentially, it is the coefficient of determination $\mathrm{r} 2$.

$$
r^{2}=\left[\frac{n \sum_{i=1}^{n} \chi i \mathrm{Y} i-\left(\sum_{i=1}^{n} \chi i\right)\left(\sum_{i=1}^{n} Y i\right)}{\sqrt{n \sum_{i=1}^{n} \chi i^{2}-\left(\sum_{i=1}^{n} \chi i\right)^{2}} \sqrt{n \sum_{i=1}^{n} Y i^{2}-\left(\sum_{i=1}^{n} Y i\right)^{2}}}\right]
$$

The value of the coefficient of determination ranged from 0 to 1 , where $0 \leq r^{2} \leq 1$. is valid. The authors point out that if the coefficient is closer to the value of 1 , it is possible to describe the dependence of the obtained data, which are presented in the further part of the study.

It is also possible to obtain values of 4 states.

1) $0,7<|\mathrm{r}| \leq 0,8$ (pronounced linear correlation);

2) $0,8<|\mathrm{r}| \leq 0,9$ (high linear correlation);

3) $0,9<|\mathrm{r}| \leq 1$ (very high linear correlation) and

4) $r \mid=1$ (perfect linear correlation).

The authors used the settings to set the hypotheses.

$$
\begin{aligned}
& \mathrm{H}_{0:}, \mu=\mu_{0} \\
& \mathrm{H}_{1:}, \mu \neq \mu_{0}
\end{aligned}
$$

The authors made the acceptability of the set hypotheses with the level of significance $\alpha$ on the basis of the given expression.

$$
\left[\frac{\bar{x}=\mu_{0}}{\frac{\sigma}{\sqrt{n}}}\right]>Z_{\frac{a}{2}}
$$

The authors did not accept the set hypotheses with the level of significance $\alpha$ on the basis of the following assumption.

$$
\left[\frac{\bar{x}=\mu_{0}}{\frac{\sigma}{\sqrt{n}}}\right] \leq Z_{\frac{\alpha}{2}}
$$




\section{Research goals set}

This study is based on a research assumption to find rules relating to the conduct of a great number of taxpayers after they are served tax decisions containing tax amounts due by them, issued by local tax authorities and relating to their property rights resulting from their ownership of agricultural land. The authors set a primary research goal which is to determine the relationship between the tax rate and the remoteness of the land in question from the centre of a local self government unit issuing tax decisions to tax payers on their respective territory.

The next goal of the authors was to deal with the issue of setting the amount of tax resulting from the ownership of agricultural land. The authors conducted a representative survey comprising approximately $31 \%$ of the population of the Republic of Serbia living in the three selected municipalities and three cities.

The research was conducted on a random sample by having an insight into 127 issued tax decisions to individual taxpayers and by having an insight into their complaints on the amounts of tax assessed on the basis of their ownership of agricultural land. The range of tax rates was from 0.2 to $0.4 \%$ in the three municipalities and three cities under consideration. The population of the said municipalities varied from 26.000 to 88.000 , and the population of cities varied from 132.000 to 2 million.

Tax amounts are set on the basis of 4 zones, depending on the remoteness of agricultural land from the centre of local municipalities or cities. One should bear in mind that zone 1 is closest to the centre and the amount of the respective tax is the highest, whereas zone 4 is the most distant from the centre and therefore the tax amount assessed is the lowest.

\section{Hypotheses}

In order to reach valid positions relating to the application of tax rates on agricultural land the authors set the following hypotheses:

H1: There is no difference in setting tax rates by tax bodies of local self governments and cities applicable to taxpayers on the basis of their ownership of agricultural land;

$\mathrm{H} 2$ : There is no difference in the tax amounts assessed to taxpayers on the basis of their ownership of agricultural land by local tax authorities irrespective of the size of municipalities or cities, measured by the population of the respective places and cities on the one, and with regard to the position of agricultural land or a zone in relation to the centre of a place or city on the other hand.

H3: There is no difference in the amount of subsequently assessed amounts of tax on property rights resulting from the ownership of agricultural land as a result of complaints lodged by taxpayers to local tax authorities. 


\section{Statistical analyses}

The statistical software program SPSS IBM was used for data processing. As an initial insight into the data, descriptive statistics were made, more precisely, the frequencies of the representation of the used variables in the sample were calculated, and then the absence of extreme values and the missing data were determined.

After that, in order to gain further insight into the relations of the used indicators, the Crosstabs option, or cross frequencies, was made in order to see the mutual relations of the variables. Given the need to respond to the needs of the first hypothesis in question, the Hi square test analysis was carried out, which corresponds to the need to monitor the differences between the variables of the categorical type.

For the needs of the second and third hypotheses, a multivariate analysis of variance was carried out, with follow-up post-hoc tests (Tukey HSD), to track differences in the categories of independent variables. Subsequently, for the purposes of the last hypothesis, a t-test for repeated measurements, as well as accompanying descriptive indicators, was made in order to gain insight into the changes in the displayed pairs of variables.

\section{Future Impacts}

The obtained results in the work can serve as guidelines for further research that monitors the tax issues related to the formation of a tax base based on ownership over agricultural land in the Republic of Serbia. In addition, the results point to the future directions that the tax authorities must undertake to reduce the dissatisfaction of taxpayers in large cities because they are in an unequal position in relation to taxpayers of small and medium-sized municipalities and cities.

By doing so, it essentially imposes substantive work on balancing the amount of tax under the ownership of agricultural land, which would accelerate state tax administration, and reduce the taxpayers' dissatisfaction with the ruthless management of state bodies.

The results of the research may be relevant for other countries, especially for the countries of the Western Balkans, as well as for a large number of transition countries.

\section{Results and Discussions}

The amount of tax created by tax authorities of local governments of the Municipality and the City can have a large number of implications for the life of an ordinary person, but also of legal persons who exist in a particular location.

There are permanent measurable impacts in the form of demands for agricultural areas to be converted into areas where some other activity in relation to agriculture will take place as they can achieve higher profit rates than agriculture.

Unrealistically high tax rates by state authorities imply dissatisfaction with taxpayers, which essentially means that the management of state bodies is not in the function of normal economic functioning. 


\section{Tax rate}

The tax rate based on ownership over agricultural land is manifestly manifested in terms of the nominal amount of tax that the tax authority of the local self-government delivers to the taxpayer on that basis.

The basis of the research results is based on the H1 setting: there is no difference in terms of determining the tax rate based on ownership over agricultural land in the Republic of Serbia.

On this basis, the authors presented the results of the research in Table 1 and Table 2, where they essentially analyzed 3 Municipalities and 3 Cities in relation to the tax rates formed by the tax authorities of the analyzed local governments.

Table 1. Frequency of local self-governments crossed with tax rates

\begin{tabular}{|c|c|c|c|c|c|}
\hline \multirow{2}{*}{$\begin{array}{c}\text { Local } \\
\text { governments }\end{array}$} & \multicolumn{4}{|c|}{ Tax rate } & \multirow{2}{*}{ Total } \\
\hline & 0.3 & 0.2 & 0.25 & 0.4 & \\
\hline $\mathrm{A}$ & 23 & 0 & 0 & 0 & 23 \\
\hline $\mathrm{B}$ & 23 & 0 & 0 & 0 & 23 \\
\hline C & 0 & 20 & 0 & 0 & 20 \\
\hline $\mathrm{D}$ & 0 & 0 & 20 & 0 & 20 \\
\hline E & 0 & 0 & 0 & 20 & 20 \\
\hline $\mathrm{F}$ & 21 & 0 & 0 & 0 & 21 \\
\hline Total & 67 & 20 & 20 & 20 & 127 \\
\hline
\end{tabular}

Note refers to the symbols of the designated municipalities and cities: (A=Zrenjanin; $\mathrm{B}=$ Kanjiža; $\mathrm{C}=$ Ruma; $\mathrm{D}=$ Sremska Mitrovica; $\mathrm{E}=$ Novi Sad; F=Beograd)

Source: authors' calculation

The frequencies shown in Table 1 provide an initial insight into the different levels of tax rates brought by tax authorities of local self-government units. In addition, it can be noted that the rate of tax on property rights over agricultural land is higher in the largest cities (Novi Sad (E) and Belgrade (F)) compared to smaller municipalities and cities.

In order to strengthen the results presented in Table 1, the authors carried out a Hi square test to establish a statistical confirmation. After that, the authors presented the results of the research in Table 2.

Table 2. Display results Hi square test

\begin{tabular}{|l|c|c|c|}
\hline & Value & df & Asymp. Sig. (2-sided) \\
\hline Pearson Chi-Square & $381.000^{\mathrm{a}}$ & 15 & .000 \\
\hline Likelihood Ratio & 307.507 & 15 & .000 \\
\hline Linear-by-Linear Association & 23.570 & 1 & .000 \\
\hline N of Valid Cases & 127 & & \\
\hline
\end{tabular}

Source: authors' calculation 
The results obtained after the conducted QQ square test, support the existence of a statistically significant difference between the established tax rate by the tax authorities of the local self-government units in relation to the size of the municipality and the city, as the value obtained $(\mathrm{p}=.00)$ is such that the tax rates are higher in larger municipalities and larger cities in the Republic of Serbia. Essentially, based on the results disclosed in Table 1 and Table 2, H1 can be completely rejected.

\section{Tax rate in relation to the number of inhabitants of the local self-government and zoning}

The tax rate based on ownership over agricultural land is continuously delivered to taxpayers through the decision of tax authorities. This statement was the basis for the formation of another hypothesis by the author. Namely, the authors proceeded from the assumption that there is no difference in terms of the amount of tax due to ownership over agricultural land, which, in the form of a decision to the taxpayer, is submitted by the tax authorities of the local self-government of the Municipalities and the City, regardless of their size measured by the number of inhabitants in relation to the zone in which the agricultural parcel is located.

Using the multivariate ANOVE, the authors presented the results in Table 3, which indicate that there are differences in the amount of the taxpayer's tax base in relation to the size of the local self-government units measured by the number of inhabitants.

Table 3. Multivariate ANOVA

\begin{tabular}{|l|l|l|l|l|l|}
\hline $\begin{array}{l}\text { Number of inhabitants of } \\
\text { local self-government }\end{array}$ & Value & F & $\begin{array}{l}\text { Hypothesis } \\
\text { df }\end{array}$ & Error df & Sig. \\
\hline Pillai's Trace & .545 & $36.525^{\text {b }}$ & 4.000 & 122.000 & .000 \\
\hline Wilks' Lambda & .455 & $36.525^{\text {b }}$ & 4.000 & 122.000 & .000 \\
\hline Hotelling's Trace & 1.198 & $36.525^{\text {b }}$ & 4.000 & 122.000 & .000 \\
\hline Roy's Largest Root & 1.198 & $36.525^{\text {b }}$ & 4.000 & 122.000 & .000 \\
\hline
\end{tabular}

Source: authors' calculation

The results show in Table 3 shows the significance of the difference $(p=.00)$ between the tax rate as the outcome of the variable, that is, the linear score obtained on the basis of different zones (existence of 4 zones) and the size of local self-governments, expressed by the number of inhabitants.

After that, the authors deepened the research by applying comparisons across zones. This was done to gain insight into the differences, for each of the zones individually. The results are given in Table 4. 
Table 4. Number of inhabitants of local self-government in relation to the amount of tax formed by zones

\begin{tabular}{|l|l|l|l|l|l|}
\hline $\begin{array}{l}\text { Number of } \\
\text { inhabitants of local } \\
\text { self-government }\end{array}$ & $\begin{array}{c}\text { Type III Sum of } \\
\text { Squares }\end{array}$ & df & Mean Square & F & Sig. \\
\hline Zone1 & 510167043829.635 & 4 & 127541760957.409 & 36.525 & .000 \\
\hline Zone2 & 432131860329.277 & 4 & 108032965082.319 & 42.744 & .000 \\
\hline Zone3 & 379891855740.873 & 4 & 94972963935.218 & 42.389 & .000 \\
\hline Zone4 & 371459115366.858 & 4 & 92864778841.714 & 47.182 & .000 \\
\hline
\end{tabular}

Source: authors' calculation

Based on the results presented in Table 4, there is a significant difference in taxpayers' tax amount in each of the four zones, as well as the existence of an impact in relation to the size of the local self-government measured by the number of inhabitants $(p=.00)$.

In addition, with the help of MANOVA techniques, the authors carried out analyzes on different subgroups of variables, such as the number of residents of local selfgovernment expressing the size of local self-government.

A Post-hoc Tukey HSD test was applied, which tested the existence of an individual difference. Essentially, based on the results disclosed in Table 3 and Table 4, H2 can be reliably dropped.

\section{The amount of tax after the taxpayer's appeal}

Item $\mathrm{H}: 3$ that there is no difference in the amount of tax on property rights over agricultural land in the Republic of Serbia, which tax authorities submit to taxpayers and subsequently handed down final decisions to taxpayers after the complaints of taxpayers have been declared. In addition, the authors expanded the observation of the level of tax solutions before and after appeals against 4 zones in order to obtain representative indicators.

The results of the research were shown by the authors in Table 5 .

Table 5. Arithmetical mean of the tax amount per zone, before and after appeal

\begin{tabular}{|l|c|c|c|c|}
\hline & Mean & N & Std. Deviation & Std. Error Mean \\
\hline Zone1 & & & 86197.633 & 7648.803 \\
\hline Complaint -Zone1 & 61633.07 & 127 & 576.477 & 51.154 \\
\cline { 2 - 5 } Cone2 & 2955.91 & 127 & 76660.498 & 6802.519 \\
\hline Zone3 & 54610.24 & 127 & 724.658 & 64.303 \\
\cline { 2 - 5 } Complaint Zone3 & 2370.08 & 127 & 72002.820 & 6389.217 \\
\hline Zone4 & 51334.65 & 127 & 641.283 & 56.905 \\
\cline { 2 - 5 } Complaint -Zone4 & 2210.24 & 127 & 69669.314 & 6182.152 \\
\cline { 2 - 5 } & 49498.43 & 127 & 613.024 & 54.397 \\
\hline
\end{tabular}

Source: authors' calculation 
This gave an initial view of the achieved average values of tax rates per zone, before and after appeal to the decisions of the tax authorities. After the presentation of Table 5, large differences were observed, which were further tested with appropriate statistical tests.

Subsequently, the authors carried out the T-test, which carried out repeated measurements in order to confirm the significance of the previously reported differences in the amount of tax before and after the taxpayers' filed complaints by zones (Table 6).

Table 6. Presentation of established tax to taxpayers before and after the appeal in zones

\begin{tabular}{|c|c|c|c|c|c|c|c|c|}
\hline & \multirow[t]{2}{*}{ Mean } & \multirow[t]{2}{*}{$\begin{array}{c}\text { Std. } \\
\text { Deviation }\end{array}$} & \multirow{2}{*}{$\begin{array}{l}\text { Std. } \\
\text { Error } \\
\text { Mean }\end{array}$} & \multicolumn{2}{|c|}{$\begin{array}{l}\text { 95\% Confidence } \\
\text { Interval of the } \\
\text { Difference }\end{array}$} & \multirow[t]{2}{*}{$\mathbf{t}$} & \multirow[t]{2}{*}{ df } & \multirow[t]{2}{*}{$\begin{array}{c}\text { Sig. } \\
\text { (2-tailed) }\end{array}$} \\
\hline & & & & Lower & Upper & & & \\
\hline $\begin{array}{l}\text { Zone1 - } \\
\text { Complaint- } \\
\text { Zone1 }\end{array}$ & 58677.165 & 85723.743 & 7606.752 & 43623.627 & 73730.704 & 7.714 & 126 & .000 \\
\hline $\begin{array}{l}\text { Zone2 - } \\
\text { Complaint- } \\
\text { Zone2 }\end{array}$ & 52240.157 & 76008.151 & 6744.633 & 38892.727 & 65587.588 & 7.745 & 126 & .000 \\
\hline $\begin{array}{l}\text { Zone3 - } \\
\text { Complaint- } \\
\text { Zone3 } \\
\end{array}$ & 49124.409 & 71479.794 & 6342.806 & 36572.183 & 61676.636 & 7.745 & 126 & .000 \\
\hline $\begin{array}{l}\text { Zone4 - } \\
\text { Complaint- } \\
\text { Zone4 }\end{array}$ & 47633.858 & 69261.147 & 6145.933 & 35471.238 & 59796.479 & 7.750 & 126 & .000 \\
\hline
\end{tabular}

Source: authors' calculation

Essentially, on the basis of the results disclosed in Table 5 and Table 6, H3 can be rejected because the significance of the difference $(p=.00)$ was obtained in all four observed zones where the agricultural parcel of the taxpayers was located, which was compared with the amount of tax solutions before and after the appeal of taxpayers.

\section{Conclusion}

The authors in this paper indicate in a comprehensive way the significance of a realistic and fairly determined amount of tax on property rights relating to agricultural land in the Republic of Serbia. Besides, the authors point out in a transparent way that the amount of tax stated in tax decisions served to taxpayers by local tax authorities needs to be realistic because, being contrary to that, it could lead to a number of undesired consequences. Unreasonably high taxation can reduce trade in agricultural land and in a more drastic event, it could result in failure to register trade in agricultural land, as taxpayers will not be willing to pay unreasonably high tax. As a less drastic option, in case of high tax amounts assessed to the owners of agricultural land, taxpayers will lodge complaints on the tax decisions made by tax authorities and served upon them, which would result in problems in the functioning of bodies of local self-government units. 
When this study is concerned, the first conclusion we reach at is that there are differences in the rates of tax on property rights resulting from the ownership of agricultural land. $\mathrm{H}: 1$ is rejected as results presented in Table 1 show that tax decisions issued by local self-governments prove there are different tax rates on the state level set by tax units of local self-governments or cities, and the greatest discrepancy is visible in two biggest cities in the Republic of Serbia the population of which accounts for approximately $1 / 3$ of the total population. This is statistically confirmed by the results shown in Table 2 . The authors determined by applying the Chi squared test that there were statistically significant differences between tax rates set by municipalities and cities $(p=.00)$. We point out that it is undoubtedly determined that tax authorities in big cities made tax decisions in which far higher tax rates were applied in assessing tax amounts charged to the respective taxpayers.

The second conclusion relating to the study is that there are differences in tax decisions issued to taxpayers by tax units of local self-governments and cities with regard to the population of the respective municipalities and cities. $\mathrm{H}$ : 2 is rejected after presenting the obtained results (Table 3$)$, as there is a significant difference $(p=.00)$. The results are supported by comparing the population and zones in which agricultural land is located (Table 4), as it is found that there is a difference in tax amounts $(p=.00)$ in all municipalities and cities if local self-government size factor is taken into account, or in other words, the number of inhabitants relative to the zoning.

The third conclusion relating to the study is that there are differences in tax decision amounts served before and following the complaints lodged by taxpayers (Table 5) with regard to the zones in which agricultural land in located. The results obtained require rejection of $\mathrm{H}: 3$, in particular after repeating the tests, as there is a high level of significance $(\mathrm{p}=.00)$ visible in Table 6 . The authors point out that ununiformly assessed tax in different local self-government units in the country leads to dissatisfaction of taxpayers who, instead of focusing on the organization of their agricultural activities, waste time and energy on lodging complaints on tax decisions issued by local tax units. The results confirming that are shown in Table 5 (Std. Deviation prior to final complaint in zone $1=86197.633$, and eventually being 576.477 following the complaint lodged by taxpayers). The last observation is evident after comparing the arithmetic mean (medium for zone $1=58677.165$, zone $4=47633.858$ ), (Table 6).

This study does not exhaust a possibility of a comprehensive observation of setting tax rates of property tax relating to agricultural land ownership. The study indicates there is a need to impose a realistic tax on property rights relating to the ownership of agricultural land as part of national level tax policy. By accepting the main conclusions of the study there would be numerous benefits both for the state and taxpayers. Therefore, the authors believe the study meets the above stated research requirements. There is a possibility of upgrading the research in order to find additional benefits for all parties mentioned in the study. 


\section{Conflict of interests}

The authors declare no conflict of interest.

\section{References}

1. Alibegović, D., Hodžić S., Bečić, E. (2018). Limited Fiscal Autonomy of Croatian Large Cities, Lex Localis - Journal of Local Self-Government, 16, 1, 107-128. http://pub.lex-localis.info/index.php/LexLocalis/article/view/1452

2. Aczel,A. D., (2015). Sounderpandian, J. Complete business statistics edition, $M_{c}$ Grew-Hill.

3. Anwar, S. \& Sun, S. (2015). Taxation of labour income and the skilled-unskilled wage inequality. Economic Modelling, 47: 18-22 https://doi.org/10.1016/j.econmod.2014.12.037

4. Barker, R. \& McGeachin, A. (2013). Why is there inconsistency in accounting for liabilities in IFRS? An analysis of recognition, measurement, estimation and conservatism. Accounting and Business Research. 43(6): 579-604. https://doi.org/ 10.1080/00014788.2013.834811

5. Baker, R. S., Kueng, L., McGranahan, L. \& Melzer, T. B. (2018). Do Household Finances Constrain Unconventional Fiscal Policy, Tax Policy and the Economy, 33, 1-32. https://www.nber.org/books-and-chapters/tax-policy-and-economyvolume-33/do-household-finances-constrain-unconventional-fiscal-policy

6. Baráth, L. \& Fertő, I. (2017). Productivity and Convergence in European Agriculture. Journal of Agricultural Economics, 68: 228-248 https://doi.org/10.1111/14779552.12157

7. Barlev, B. \& Haddad, J. (2003). Fair value accounting and the management of the firm. Critical Perspectives on Accounting. 14: 383-415. DOI: 10.1016/S10452354(02)00139-9

8. Boukalova, K., Kolarova, A. \& Lostak, M. (2016). Tracing shift in Czech rural development paradigm (Reflections of Local Action Groups in the media). Agricultural Economics (Zemědělská ekonomika), 62: 149-159 https://doi. org/10.17221/102/2015-AGRICECON

9. Bozzolan, S., Laghi, E. \& Mattei, M. (2016). Amendments to the IAS 41 and IAS 16 - implications for accounting of bearer plants. Agric. Econ. - Czech. 62: 160166. https://doi.org/10.17221/48/2015-AGRICECON

10. Bratten, B., Jennings, R. \& Schwab, C. (2016). The accuracy of disclosures for complex estimates: Evidence from reported stock option fair values. Accounting, Organizations and Society. 52: 32-49. https://doi.org/10.1016/j.aos.2015.09.001

11. Brousseau, C., Gendron, M., Belanger, P. \& Coupland, J. (2014). Does fair value accounting contribute to market price volatility? An experimental approach. Accounting \& Finance. 54(4): 1033-1061. https://doi.org/10.1111/acfi.12030

12. Brown, P. \& Szimayer, A. (2008). Valuing executive stock options: performance hurdles, early exercise and stochastic volatility. Accounting \& Finance. 48(3): 363-389. DOI: 10.1111/j.1467-629X.2008.00259.x 
13. Cai, F. \& Wong, H. (2010). The effect of IFRS adoption on global market integration. International Business \& Economics Research Journal. 9(10): 25-34. https://www.researchgate.net/publication/296622836

14. Cantino, V. (2009). Corporate governance, performance measurement and regulatory compliance of the internal control system. DataStatus, Belgrade. [in Serbian: Cantino, V. (2009). Korporativno uptravjanje, merenje performansi i normativna usaglašenost sistema internih kontrola. DataStatus, Beograd].

15. Chen, H., Wang D., Zhou N. A (2017). Comprehensive and Quantitative Internal Control Index: Construction, Validation, and Impact, Review of Quantitative Finance and Accounting, 49, 337-377. https://ideas.repec.org/a/kap/rqfnac/ v49y2017i2d10.1007_s11156-016-0593-x.html

16. Murphy, R. (2019). 'Corporate tax avoidance: is tax transparency the solution?': a practitioner view, Accounting and Business Research, 49, 5, 584-586. https:// www.tandfonline.com/doi/abs/10.1080/00014788.2019.1611728

17. Novaković, S., Vukasović, D., Laban, B.,Ivić, M., Popović, V. \& Popović, S. (2018). Managing agricultural company by using internal control and significance of risk presentation, Economics of Agriculture, 2: 801-812. doi:10.5937/ekoPolj1802801N

18. Nowak, A., Janulewicz, P., Krukowski, A. \& Bujanowicz-Haraś, B. (2016). Diversification of the level of agricultural development in the member states of the European Union. Cahiers Agricultures, 25: 55004. https://doi.org/10.1051/cagri/2016040

19. Popović, S. (2014). Socio-economic factors limiting the development of agrarian, Feljton, Novi Sad. [in Serbian: Popović, S. (2014). Socio-ekonomski faktori ograničenja razvoja agrara, Feljton, Novi Sad].

20. Popović, S., Mijić, R. \& Grublješić, Ž. (2014a). Internal control and internal audit in the function of management, Škola Biznisa, 1, 95-107. [in Serbian: Popović, S., Mijić, R. i Grublješić, Ž. (2014a): Interna kontrola i interna revizija u funkciji menadžmenta, Škola Biznisa, 1, 95-107].

21. Popović, S., Majstorović, A. \& Grublješić Ž. (2015). Valuation of facilities in use and application of international accounting standards, Actual problems of economics, 3(165): 379-387. https://eco-science.net/en/downloads

22. Popović, S., Đuranović, D., Laban, B., Ivić, M., Jovin, S., Nastić, S., Grublješić, Ž. \& Popović, V. (2018). Impact of different light intensity on the production of the plant narcissus 1. and its financial effects, Economics of Agriculture, 4: 1359-1370. doi:10.5937/ekoPolj1804359P

23. Popović, D., Vitomir, J., Tomaš-Miskin, S., Davidov, T., Popović, S., Jovanović, M., Aćimić-Remiković, M. \& Jovanović, S. (2021). Implementation of internal control with reference to the application of "it" in companies operating on the principles of the green economy. Agriculture \& Forestry, 67(2): 261-269. http:// www.agricultforest.ac.me/data/20210630-19\%20Popovic\%20et\%20al.pdf. 
24. Radović, M., Vitomir, J. \& Popović, S. (2021). Impact of internal control in enterprises founded by local self-government units: the case of Republic of Serbia, Inzinerine Ekonomika-Engineering Economics, 32(1), 82-90; DOI: https://doi.org/10.5755/j01.ee.32.1.23243.

25. Rymanov, A. (2017). Differential land rent and agricultural taxation. Agric. Econ. - Czech, 63, 9, 421-429. https://www.agriculturejournals.cz/web/agricecon. htm?type=article\&id=127_2016-AGRICECON

26. Rodriguez, M., Miguel, Sanchez, L., Cejudo, E. \& Antonio, C. (2019). Variety in local development strategies and employment: LEADER programme in Andalusia. Agric. Econ. - Czech, 65: 43-50 https://doi.org/10.17221/106/2018-AGRICECON

27. Santos Curto, H. \& Dias, Á. (2014). Administrative reforms and performance of local public policies, International Journal of Public Sector Management, 27, 6, 462-474(13). https://www.researchgate.net/publication/265857329 Administrative_reforms_and_performance_of_local_public_policies

28. Scalera, F. (2016). The Balkan Area Development: Threats and Opportunities for Italian Companies' Investment Strategies. International Journal of Business and Management, 11, 10, 37-50. https://ideas.repec.org/a/aml/intbrm/ v10y2019i4p64-83.html

29. Soltani, B. (2009). Audit, International Approach, Mate, Zagreb. [in Serbian: Soltani, B. (2009). Revizija, Međunarodni pristup, Mate, Zagreb].

30. Ugrenović, V., Popović, V., Ugrinović, M., Filipović, V., Mačkić, K., Ljubičić, N., Popović, S. \& Lakić, Ž. (2021). Black Oat (Avena strigosa Schreb.) Ontogenesis and Agronomic Performance in Organic Cropping System and Pannonian Environments, Agriculture, 11(1), 55; https://doi.org/10.3390/agriculture11010055

31. Vitomir, J., Radović, M. \& Popović, S. (2021). The Effect of Public Finance Control on the Improvement of Work of Internal Auditors in Enterprises Founded by the Local Self-government Units on the Example of the Republic of Serbia, Lex localis - Journal of Local Self-Government, 19(2). DOI: https://doi.org/10.4335/19.2.245-261(2021).

32. Vukadinović, S. V. (1990). Elements of probability theory and mathematical statistics, Privredni pregled, Beograd. [in Serbian: Vukadinović, S. V. (1990). Elementi teorije verovatnoće i matematičke statistike, Privredni pregled, Beograd].

33. Wang, D. (2019). Manufacturing and agricultural pollution, private mitigation and wage inequality in the presence of pollution externalities. Agric. Econ. - Czech, 65: 51-58 https://doi.org/10.17221/79/2018-AGRICECON

34. Williams, C. (2010). Principles of management, DataStatus, Belgrade. [in Sebian: Williams, C. (2010). Principi menadžmenta, DataStatus, Beograd].

35. Wynen, J. \& Verhoest, K. (2016). Internal Performance-Based Steering in Public Sector Organizations: Examining the Effect of Organizational Autonomy and External Result Control, Public Performance \& Management Review, 39,3, 535 559. https://www.tandfonline.com/doi/abs/10.1080/15309576.2015.1137769 